\title{
Can soybean biomass addition optimize corn silage quality?
}

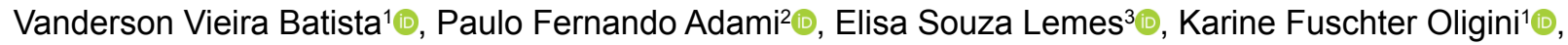

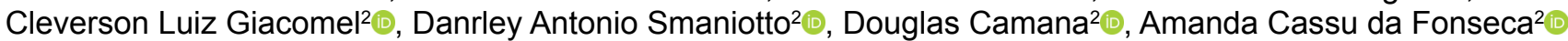

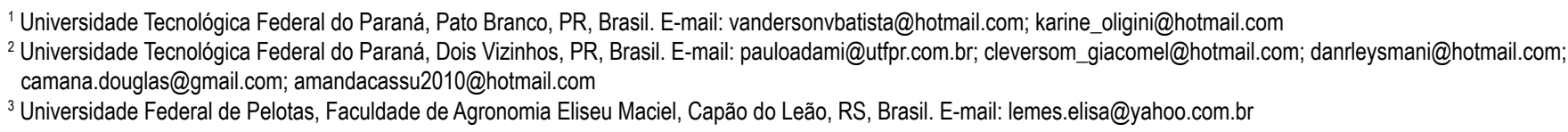

ABSTRACT: Maize silage is the main conserved roughage used in animal feed in Brazil and improving its quality has great relevance. The aim of this experiment was to evaluate the characteristics of maize silage, containing different percentages of soybean biomass. In this way, different percentages of soybean green biomass added to maize ensilage $(0,10,20,30$ and $40 \%$ - experiment 1 and 0,10,20,30, 40 and 50\% in experiment 2) were evaluated. Experiments were laid out as a completely randomized. Variables were submitted to analysis of variance and when it present significance was applied regression analysis. Silage ashes increased as soybean biomass increased. Regarding to the neutral and acid detergent fiber and the amount of total digestible nutrients, there was no effect of the treatments. At experiment 1, silage crude protein increased from 7.5 to $12.6 \%$ from sole maize silage to the silage with $39.2 \%$ of soybean dry biomass, which represent an increase of $67.24 \%$. At experiment 2 , it increased from 6.77 to $12.09 \%$, which represent $78.58 \%$ more protein at the treatment with $50 \%$ of soybean green biomass $(41 \%$ dry matter of soybean) in relation to the sole maize silage. At experiment 2 , for every $1 \%$ increase in soybean dry matter biomass addition, there was an increase of $0.1 \%$ of maize silage crude protein. The addition of soybean biomass to corn silage increases the ashes and crude protein content of silage.

Key words: ashes; crude protein; digestibility; Glycine max; Zea mays

\section{A adição de biomassa de soja pode otimizar a qualidade da silagem de milho?}

RESUMO: A silagem é o principal volumoso conservado utilizado na alimentação animal no Brasil e melhorar sua qualidade, apresenta grande relevância. Objetivo deste estudo é avaliar características da silagem de milho, contendo diferentes porcentagens de biomassa de soja. Avaliaram-se diferentes frações de biomassa verde de soja, adicionadas a ensilagem de milho $(0,10,20,30$ e 40\% - experimento 1 e 0,10,20,30, 40 e 50\% no experimento 2). Utilizou-se delineamento inteiramente casualizado. As variáveis avaliadas foram submetidas à análise de variância e havendo efeito significativo aplicou-se análise de regressão. A matéria mineral da silagem aumentou de forma linear com a elevação das porcentagens de soja, entretanto não influenciaram fibra em detergente neutro e ácido, e a quantidade de nutrientes digestíveis totais. No experimento 1, o teor de proteína bruta da silagem aumentou de 7,5 para $12,6 \%$ da silagem de milho para a silagem com $39,2 \%$ de biomassa de soja, 0 que representa um aumento de $67,24 \%$. No experimento 2, a proteína bruta aumentou de 6,77 para 12,09\%, o que representa $78,58 \%$ a mais de proteína bruta no tratamento com $50 \%$ de adição de biomassa de soja verde (41\% de matéria seca de soja) em relação à silagem de milho. No experimento 2, para cada 1\% de acréscimo de biomassa seca de soja, tem-se elevação de $0,1 \%$ de proteína bruta. A adição de biomassa de soja a silagem de milho, eleva os teores de matéria mineral e proteína bruta da silagem.

Palavras-chave: matéria mineral; proteína bruta; digestibilidade; Glicine max; Zea mays 


\section{Introduction}

Animal feeding is increasingly discussed in the farming and scientific field (Jobim et al., 2010). According to the same researchers, further studies aiming at the use of technologies that ally efficiency and economy in animal production, are essential. Belel et al. (2014) emphasized that forage production improvement has great relevance for animal production, being a fundamental factor in the current production systems. In addition, the use of conserved silage is a well-known option in Brazil, especially in periods of lack of green fodder (Stella et al., 2016).

For the ensiling process, maize (Zea mays L.) stands out as the main used forage crop, due to its high dry matter yield per area, sufficient amount of sugars for the production of lactic acid, good fermentation, providing a feed with approximately $7.7 \%$ of crude protein (Goes et al., 2013). Despite that, studies have been showing that the addition of legume biomass, including soybean, has the potential to increase silage yield (Baghdadi et al., 2016; Tsujimoto et al., 2016) and enhance the quality of corn silage, especially the crude protein content (Keplin 2004; Stella et al., 2016; Kim et al., 2018; Batista et al., 2018; Batista et al., 2019).

According to Stella et al., (2016), maize silage presents $7.31 \%$ of crude protein, and this value increased to 10.5 and $13.6 \%$, with the addition of 25 and $50 \%$ of soybean dry matter biomass, respectively. Likewise, Keplin (2004) points out that soybean silage may produce 2.5 times more crude protein per kilogram of dry matter compared to corn silage.

Thus, its inclusion/addition level should be carefully evaluated to avoid problems in the fermentation process and bromatological quality of silage caused by the amount of water present in plants (Ghizzi et al., 2017). Evangelista et al. (2003) reported bad silage fermentation when soybean was ensiled alone due to its higher water content. Due to it, further investigations are necessary to explore the effect of different proportions between maize and soybean biomass and their effects on silage quality.

It is worth noting that among legume species, soybean is one of the best options to be used as intercrop specie with maize for silage production. There are many transgenic events for pest and weed management, as well as aspects that allow cultivation in several regions, with a great supply and low cost of seeds when compared to other legumes.

Considering these facts, the aim was to evaluate the effect of different percentages of soybean biomass addition on the Bromatological traits of corn silage.

\section{Materials and Methods}

This experiment was carried out during 2017/2018 growing season at Agricultural Research Station and the Bromatological Analysis Laboratory of the Federal Technological University of Paraná (UTFPR), campus of Dois Vizinhos, located at 25 42'

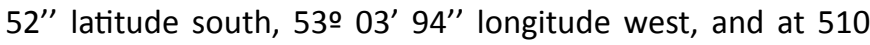
$\mathrm{m}$ above sea level. The experimental area has a consolidated no-tillage system with the climate classified as Cfa (Alvares et al., 2013). The soil is classified as a Clayey Oxisol (Bhering et al., 2009). The average rainfall ranges from 1,800 to $2,200 \mathrm{~mm}$ per year (IAPAR, 2019).

Two studies in a completely randomized design with four replications were conducted. Treatments were composed by adding percentages of soybean green biomass into maize ensiling. At experiment 1 , soybean green biomass addition of $0,10,20,30$, and $40 \%$ into maize silage were evaluated and at experiment 2 were kept the same levels adding a treatment with $50 \%$ of soybean green biomass.

At the first experiment, maize (P30F53 hybrid) and soybean (TMG 7062 Intacta RR2 Pro) biomass samples were collected from commercial crop fields grown as the UTFPR experimental station. Maize kernel milk line stage ( $1 / 2$ milk $1 / 2$ dough stage) was used as an indicator of when to harvest maize fields to silage. Soybean phenological stage of 7.0- beginning maturity (one normal pod on the main stem has reached its mature pod color) was determinated at the right moment to harvest soybean for silage, which according to Leonel et al. (2008), allows to obtain the higher silage crude protein levels.

Considering the results from the first experiment and the benefits provided by maize and soybean intercropped reported in the literature research (Baghdadi et al., 2016; Tsujimoto et al., 2016), the second experiment was carried out in an intercropping system. Maize hybrid 2B533PW and soybean cultivar TMG 7062 Intacta RR2 Pro was used as plant material.

On October 02, 2017, the intercrop of maize and soybean was sown simultaneously, using a seed drill with maize seed disc of 28 holes and soybean seed disc of 100 holes. Seed drill regulation was set up to sow 62.000 maize seeds ha-1 and consequently 221.429 soybean seeds ha-1. Intercropping was obtained by alternating four maize rows with four soybean rows, with $30 \mathrm{~cm}$ row spacing (Figure 1 ).

The experimental site of the second experiment has been cultivated for years in a no-tillage system, with crop rotation. Soil showed the following traits: $57 \%$ clay, $33 \%$ silt and $10 \%$

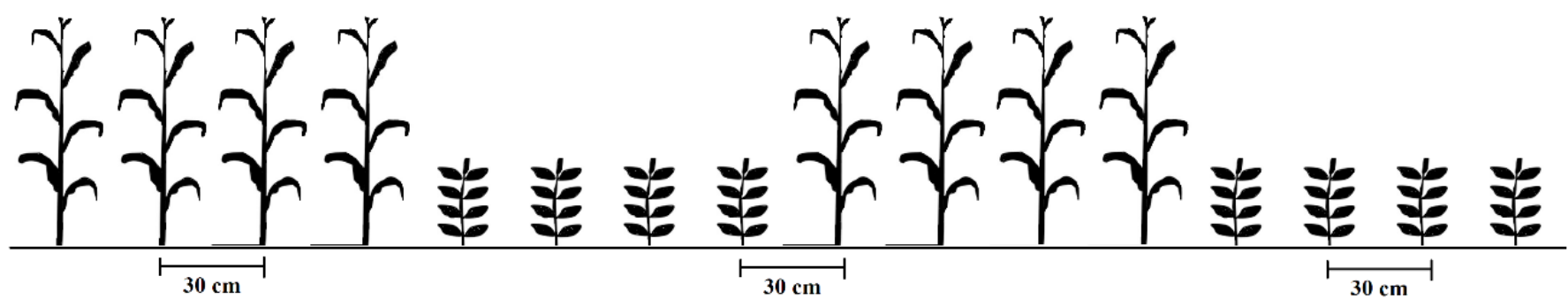

Figure 1. Row arrangement of maize and soybean intercropped for silage. UTFPR - Dois Vizinhos-PR, Brazil (2019). 
sand, and chemical properties in the $0-20 \mathrm{~cm}$ layer of 3.43 , 4.30, 0.90, and $0.90 \mathrm{cmol}_{\mathrm{c}} \mathrm{dm}^{-3}$ for $\mathrm{H}+\mathrm{Al}, \mathrm{Ca}, \mathrm{Mg}$, and $\mathrm{K}$ respectively. It was also observed values of $21.63 \mathrm{mg} \mathrm{dm}^{-3}$ of $\mathrm{P}$, organic matter $44.23 \mathrm{mg} \mathrm{dm}^{-3}, \mathrm{pH} 5.20$, and base saturation $64.08 \%$.

Temperature and precipitation data observed during the second experiment are shown in Figure 2.

Black oat (Avena strigosa) was used as prior crop and it was desiccated with glyphosate (1.080 $\mathrm{g} \mathrm{ha}^{-1}$ of active ingredient) 30 days before intercrop establishment.

At sowing, fertilization was used for both species adding $450 \mathrm{~kg} \mathrm{ha}{ }^{-1}$, of chemical fertilizer 5-20-10 (N- $\left.\mathrm{P}_{2} \mathrm{O}_{2}-\mathrm{K}_{2} \mathrm{O}\right)$. Nitrogen $(\mathrm{N})$ was applied as urea (45\% of $\mathrm{N}$ ) at the rate of 180 $\mathrm{kg} \mathrm{N} \mathrm{ha-1}$. Half of the $\mathrm{N}$ dose was applied at V4 (collar of fourth leaf visible) (three weeks after sowing) and the remaining half at V8 (collar of $8^{\text {th }}$ leaf visible), all by side placement manually along the rows. Insecticide imidacloprid + beta-cyfluthrin at the dose of $1 \mathrm{~L} \mathrm{ha}^{-1}$ was applied, shortly after maize emergence to control stink bug (Dichelops melacanthus). Weed control was achieved by applying glyphosate ( $1.2 \mathrm{~g}$ a.i.ha ${ }^{-1}$ ) on maize at V3 stage (collar of third leaf visible). Fungicide application was done at maize blister (R2 stage) with a systemic ready mixture product containing estrobilurina + pirazol carboxamida at a commercial dose of $300 \mathrm{~g} \mathrm{ha}^{-1}$. Along with the fungicide, vegetable oil was added at a dose of $0.5 \mathrm{~L} \mathrm{ha}^{-1}$ and spray volume of $160 \mathrm{~L} \mathrm{ha}^{-1}$ applied with a self-propelled sprayer.

Maize ensiling point occurred on 01/30/2018, which happened 120 days after its emergence. At that point, soybean cultivar was at 5.3 phenological stage (seeds are between 25 and $50 \%$ developed at one of the four upper nodes on the main stem).

At the corn silage point, in both studies, corn and soybean plants were harvested by hand cutting the plants at $25 \mathrm{~cm}$ above soil surface. Plants from experimental unit were harvested in four sampling area of $4.5 \mathrm{~m}^{2}(5.0 \times 0.9 \mathrm{~m})$ for experiment 1 and $4.8 \mathrm{~m}^{2}(4.0 \times 1.2 \mathrm{~m})$ for experiment 2 . The samples were weighed to determine maize and soybean biomass yield, being the values extrapolated to hectare $(\mathrm{kg}$ $\mathrm{ha}^{-1}$ ) (green biomass (GB)).

Then, samples of both crops of each experimental unit (EU) were ground separately on a forage harvester coupled to a tractor with an average particle size of $1.5 \mathrm{~cm}$. Four subsamples of soybean and corn ground biomass with $300 \mathrm{~g}$ each were placed in paper bags and oven-dried with forced air circulation at $65{ }^{\circ} \mathrm{C}$ until constant mass to determinate its dry matter content of each experiment.

Samples of $3 \mathrm{~kg}$ of biomass were prepared (corn green biomass + fraction of soybean green biomass), mixed for total homogenization and packed compactly into Laboratory silos made of PVC pipes, measuring $100 \mathrm{~mm}$ in diameter and 500 $\mathrm{mm}$ in length. At the time of ensiling, the silos were sealed with PVC caps and stored for 60 days for fermentation.

Upon the opening of the silos, the determination of $\mathrm{pH}$ was carried out in the silage in accordance with the methodology described by Silva \& Queiroz (2002). Samples collected (300 g) after the opening of the silos were placed in paper bags and oven-dried with forced air circulation at $65^{\circ} \mathrm{C}$ until constant mass. Dried samples were ground in a 'Willey' type mill with a $1 \mathrm{~mm}$ mesh sieve, and the samples taken to the Bromatological Analysis Laboratory of the UTFPR.

Further analysis of dry matter, ashes (\%) (Silva \& Queiroz, 2002), neutral detergent fiber (NDF), acid detergent fiber (ADF) (\%) were determined by the methodology described in the Ankom (2009) manual. TDN = 87.84 - (0.7 × ADF) (Pionner, 2019) was used to estimate the total digestible nutrients (TDN). Silage crude protein (SCP) $\left(\mathrm{g} \mathrm{kg}^{-1}\right)$ analysis was performed by quantifying the $\mathrm{N}$ present in the samples, with the total $\mathrm{N}$ being determined in Kjeldhal semi-micro steam distillation methodology (Tedesco et al. 1995).

Dry mass and biomass yield values for crop silage are presented in a descriptive way. The other variables were submitted to analysis of variance (ANOVA) $(p<0.05)$ and

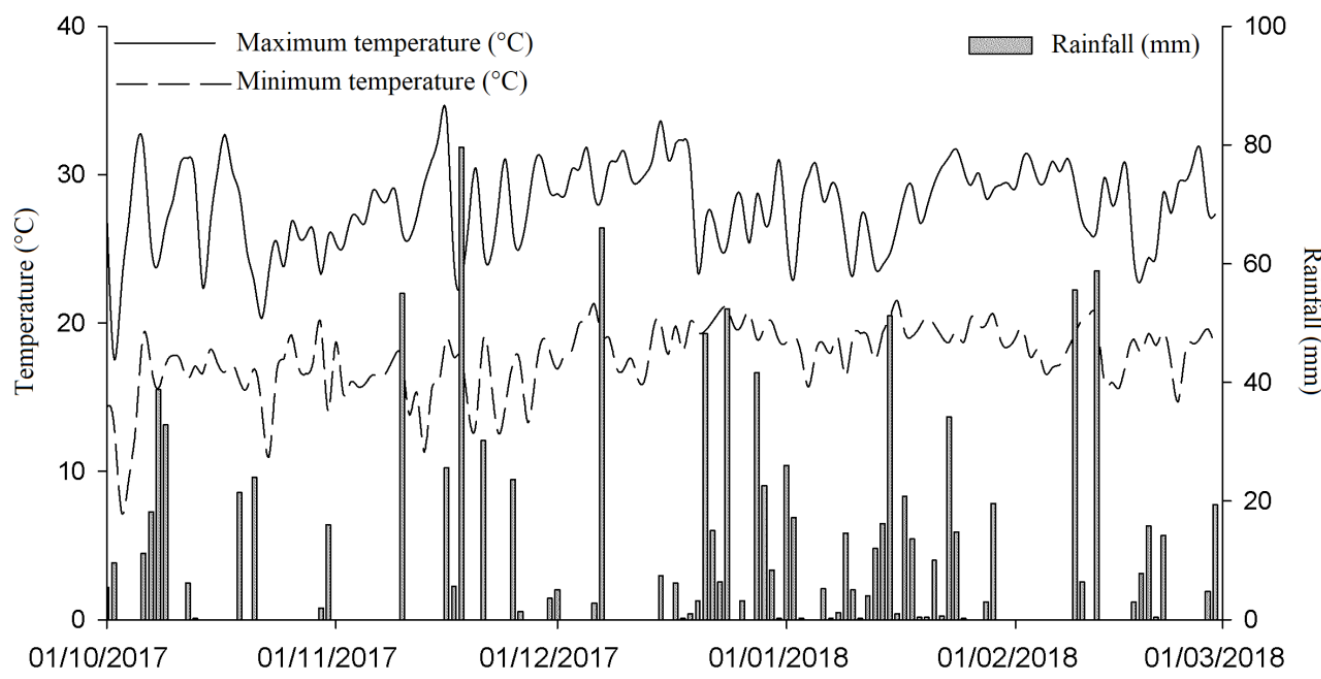

Source: IAPAR (2019).

Figure 2. Maximum and minimum temperature $\left({ }^{\circ} \mathrm{C}\right)$ and rainfall $(\mathrm{mm})$ recorded during the intercropping Maize and soybean for silage. UTFPR - Dois Vizinhos-PR, Brazil (2019). 
when it present significance was applied linear and quadratic regression analysis. For analysis of data, Sisvar 5.6 (Ferreira, 2008) software was used.

\section{Results and Discussion}

At the ensiling point (Experiment 1), maize and soybean crop showed a dry matter (DM) value of 34.1 and $29.7 \%$ respectively. At the second experiment, these values were of 35.8 and $24.9 \%$ respectively. The difference between the studies for soybean biomass ( $4.8 \% \mathrm{DM})$ is related to the phenological stage at the time of cutting and/or ensiling. At the first experiment, the legume was at the 7.0 phenological stage and in the second at 5.3. Because of this difference in DM contents of the crops, it was observed that the DM proportions in the silage, changed in relation to the proportion of green biomass (GB) placed into the silos (Table 1).

It is worth to comment that when a silo is made, the farmer is ensilaging green biomass, and thus, as a research source, the green mass content of the silage should be considered.

The analysis of variance (ANOVA) showed a significant effect of the evaluated treatments on ashes and crude protein from experiment 1 , and for $\mathrm{pH}$, ashes, and crude protein from experiment 2 (Table 2).

The $\mathrm{pH}$ of silage was not influenced by the percentages of soybean biomass in experiment 1 , presenting average values of 4.49. However, it was observed in experiment 2 that $\mathrm{pH}$ was influenced by the addition of soybean percentages, being the quadratic model, which best represents the results (Figure $3 A)$. According to the mathematical model $\left(y=-0.00006 x^{2}+\right.$ $0.0066 \mathrm{x}+4.3611)$, the highest $\mathrm{pH}$ values (4.54) are recorded in the silage composed of $55.00 \%$ of DM of soybean in the amount of ensiled biomass.

This increase in $\mathrm{pH}$ in the second experiment may be related to the higher percentage of moisture content in the soybean biomass. Evangelista et al. (2003), observed that the high moisture in the silo may compromise the microbial fermentation of the ensiled biomass and, consequently, changing the $\mathrm{pH}$ values of the silage.

It was observed that the $\mathrm{pH}$ values increased from 4.35 in the maize monocrop ( $100 \% \mathrm{M})$ to 4.52 in silage composed of equal fractions of maize and soybean ( $50 \% \mathrm{M}+50 \% \mathrm{~S}$ ) (experiment 2 - Figure $3 \mathrm{~A}$ ). The $\mathrm{pH}$ variation among treatments of only 0.17 allows to infer that it did not interfere in the silage quality.

Table 1. Green biomass (GB) and dry matter (DM) in maize silage with the addition of percentages of soybean biomass, UTFPRDois Vizinhos, Brazil (2019).

\begin{tabular}{|c|c|c|c|c|c|c|c|}
\hline \multirow{2}{*}{ Treatments } & \multicolumn{2}{|c|}{ GB (g) } & \multicolumn{2}{|c|}{$\overline{D M}(g)$} & \multirow{2}{*}{$\begin{array}{c}\text { Total DM (g) } \\
\text { Maize+Soybean }\end{array}$} & \multicolumn{2}{|c|}{ Total DM (\%) } \\
\hline & Maize & Soybean & Maize & Soybean & & Maize & Soybean \\
\hline \multicolumn{8}{|c|}{ Experiment 1} \\
\hline $100 \% \mathrm{M}$ & 3,000 & 0 & $1,023.0$ & 0.0 & $1,023.0$ & 100.0 & 0.0 \\
\hline $80 \% M+20 \% S$ & 2,400 & 600 & 818.4 & 178.2 & 996.6 & 82.1 & 17.9 \\
\hline $70 \% M+30 \% \mathrm{~S}$ & 2,100 & 900 & 716.1 & 267.3 & 983.4 & 72.8 & 27.2 \\
\hline $100 \% \mathrm{M}$ & 3,000 & 0 & $1,074.0$ & 0.0 & $1,074.0$ & 100.0 & 0.0 \\
\hline $90 \% \mathrm{M}+10 \% \mathrm{~S}$ & 2,700 & 300 & 966.6 & 74.7 & $1,041.3$ & 92.8 & 7.2 \\
\hline $80 \% \mathrm{M}+20 \% \mathrm{~S}$ & 2,400 & 600 & 859.2 & 149.4 & $1,008.6$ & 85.2 & 14.8 \\
\hline $70 \% \mathrm{M}+30 \% \mathrm{~S}$ & 2,100 & 900 & 751.8 & 224.1 & 975.9 & 77.0 & 23.0 \\
\hline $60 \% M+40 \% S$ & 1,800 & 1,200 & 644.4 & 298.8 & 943.2 & 68.3 & 31.7 \\
\hline $50 \% \mathrm{M}+50 \% \mathrm{~S}$ & 1,500 & 1,500 & 537.0 & 373.5 & 910.5 & 59.0 & 41.0 \\
\hline
\end{tabular}

$\mathrm{M}=$ Maize. $\mathrm{S}=$ Soybean.

Table 2. Means and P-values of the bromatological traits of maize silage with the addition of different percentages of soybean biomass. UTFPR- Dois Vizinhos, Brazil (2019).

\begin{tabular}{|c|c|c|c|c|c|c|}
\hline & $\mathrm{pH}$ & Ashes & NDF & ADF & TDN & $\mathrm{CP}$ \\
\hline \multicolumn{7}{|c|}{ Experiment 1} \\
\hline P-value (ANOVA) & $0.6498^{n s}$ & $0.0017^{*}$ & $0.1452^{\text {ns }}$ & $0.3944^{\text {ns }}$ & $0.3944^{\mathrm{ns}}$ & $0.0000^{*}$ \\
\hline Linear regression $\mathrm{P}$-value & ----- & $0.0001^{*}$ & ----- & ----- & ----- & $0.0000^{*}$ \\
\hline Quadratic regression P-value & ----- & $0.4471^{\text {ns }}$ & ----- & ----- & ----- & $0.0030 *$ \\
\hline Means & 4.49 & 5.98 & 44.04 & 23.51 & 71.38 & 10.66 \\
\hline CV (\%) & 1.29 & 9.45 & 4.96 & 9.51 & 7.20 & 6.76 \\
\hline \multicolumn{7}{|c|}{ Experiment 2} \\
\hline P-value (ANOVA) & $0.0000 *$ & $0.0099 *$ & $0.6609^{n s}$ & $0.9236^{\text {ns }}$ & $0.9236^{\text {ns }}$ & $0.0000 *$ \\
\hline Linear regression $\mathrm{P}$-value & $0.0000^{*}$ & $0.0003^{*}$ & ----- & ----- & ----- & $0.0000^{*}$ \\
\hline Quadratic regression $\mathrm{P}$-value & $0.0362 *$ & $0.8988^{\text {ns }}$ & ----- & ----- & ----- & $0.2931^{\mathrm{ns}}$ \\
\hline Means & 4.47 & 4.38 & 40.59 & 21.25 & 72.87 & 9.76 \\
\hline CV (\%) & 0.76 & 16.08 & 7.34 & 15.25 & 9.87 & 8.85 \\
\hline
\end{tabular}

* Significant at $p \leq 0.05$ level and ${ }^{\text {ns }}$ non-significant at the $p>0.05$ level. $C V=$ Coeffcient of variation; $\mathrm{pH}=$ potencial hydrogen; NDF= neutral detergent fiber; ADF = acid detergent fiber TDN = total digestible nutrients; $C P=$ crude protein. 

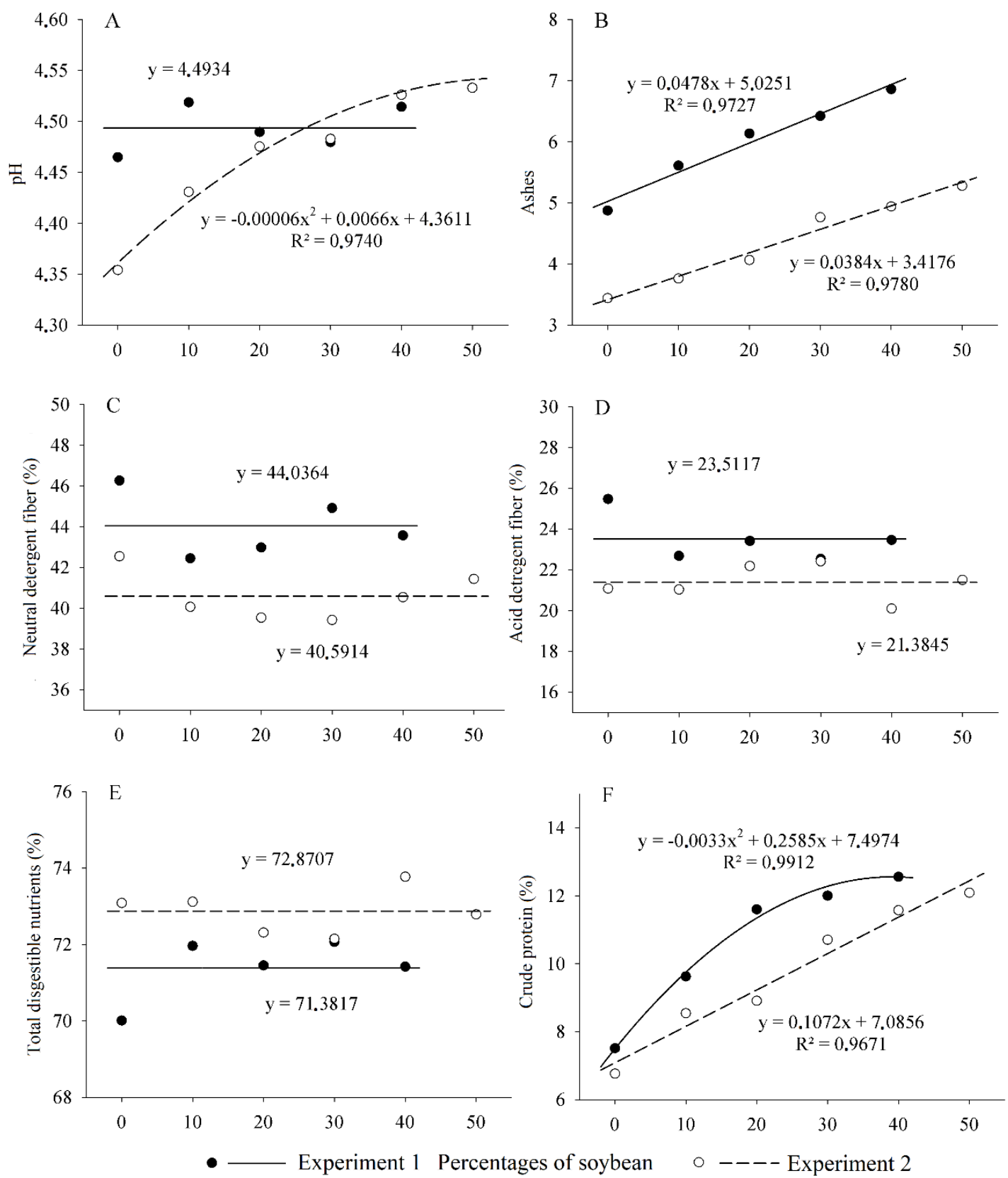

Figure 3. Bromatological traits of maize silage with the addition of different percentages of soybean biomass UTFPR - Dois Vizinhos, Brazil (2019).

According to Neves \& Gai (2017), the pH values found in the present experiment characterize good quality silage and are similar to those observed in other studies using sole maize crop silage (Neves \& Gai, 2017; Pauli et al., 2017 ) and composed silage (corn + soybean) (Stella et al., 2016; Batista et al., 2018; Batista et al., 2019). In this context, it can infer that the addition of soybean biomass does not affect the microbial fermentation of the ensiled biomass.

Regarding to the ashes, it was noticed that its silage content increased in a linear way as the proportion of soybean biomass increased (Figure 3B). A similar result was observed by Jobim et al. (2010) evaluating silage of maize grains with addition of soybean grains. According to the researchers, this performance of the ashes can be explained by the reduction of other components of the dry mass (carbohydrates), which normally occur in the process of ensilage of corn, resulting in an increase in the concentration of the ashes with the addition of the legume.

No effects of soybean biomass on neutral detergent fiber (NDF), acid detergent fiber (ADF) and total digestible nutrients (NDT) were observed (Table 2), with observed NDF values of 44.04 and $40.59 \%$ (Figure 3C), ADF of 23.51 and $21.38 \%$ (Figure 3D), and TDN of 71.38 and $72.87 \%$ (Figure 3E), for studies 1 and 2, respectively. These values are similar to those observed by Batista et al. (2019) in silages containing approximately $90 \%$ corn biomass and $10 \%$ soybean biomass (NDF - $38.34 \%$, ADF - 20.02\% and TDN- $73.83 \%$ ).

The higher concentration of NDF in the animal diet, the lower is the animal feed intake capacity (Ghizzi et al., 2017). Thus, similar fibers values observed between composed 
silages (maize and soybean) and sole maize crop silage, is somehow desired, since other silage bromatological traits were increased. Van Soest (1994) reported that adequate levels of NDF and ADF of silage for animal intake should be below $60 \%$ and $40 \%$, respectively, which are in accordance with those observed in the silages evaluated.

Regarding the crude protein, the evaluated treatments had significant effect on the percentage of crude protein of the silage (Table 2). In experiment 1 , the quadratic model is the one that best represents the system, being observed maximum efficiency point ( $12.56 \%$ of $C P$ ) when using $39.17 \%$ of soybean biomass (Figure 3F). For the sole maize crop, the value of CP was $7.51 \%$, while it was observed an increase of crude protein content of $67.24 \%$ when $39.17 \%$ of soybean dry matter biomass was added in the composed silage.

At the experiment 2, a linear increase of CP was observed as soybean biomass addition to maize silage increased (Figure $3 F$ ). Maize silage presented $6.77 \%$ of $\mathrm{CP}$ versus $12.09 \%$ in silage composed of $50 \%$ of corn and soybean green biomass (59 and $41 \%$ dry matter of corn and soybean, respectively), representing an increase of $78.58 \%$ on the protein content. Thus, each $1 \%$ increase in soybean biomass, there was an increase of $0.1 \%$ in crude protein contents (Experiment 2 ). This result shows that soybean biomass ensiling, along with maize biomass, has the potential to raise the protein content of the silage, improving its composition.

These results corroborate with other studies that evaluated these intercrop (Batista et al., 2018; Batista et al., 2019) with different proportions of ensiled biomass (Stella et al., 2016). According to Stella et al. (2016), from the standpoint of chemical composition, the ensiled corn biomass could be composed of up to $50 \%$ soybean plant, resulting in improved silage traits (CP) without affecting its fermentation quality $(\mathrm{pH}$ and $\mathrm{N}-\mathrm{NH} 3$ concentration).

Gobetti et al. (2011) emphasize that soybean biomass presents high nutritional value, compared to corn silage, and this fact may reduce the demand of concentrate in the animal diet. According to Stella et al. (2016), through the association of corn and soybeans, it is possible to reduce the ratio of roughage/concentrate in the animal diet, generating a reduction in the final cost of feeding due to the less need of protein source from a high-cost supplement, such as the soybean meal (Stella et al. 2016).

According to the results of these studies, the addition of soybean biomass in maize silage is an excellent alternative to raise the crude protein content of the silage.

Concerning to the biomass yield (Experiment 1 ) at the ensiling point, maize produced $63,449.01 \mathrm{~kg} \mathrm{ha}^{-1}$ of $\mathrm{GB}$ $\left(21,636.11 \mathrm{~kg} \mathrm{ha}^{-1} \mathrm{DM}\right)$, and soybean $18,281.62 \mathrm{~kg} \mathrm{ha}^{-1}$ of GB $\left(5,429.64 \mathrm{~kg} \mathrm{ha}^{-1} \mathrm{DM}\right)$. It is important to highlight that the crops were cultivated isolated. For experiment 2, crops were intercropped (4 row of maize and 4 row of soybean), and maize and soybean yielded $60,403.83 \mathrm{~kg} \mathrm{ha}^{-1}$ of $\mathrm{GB}(21,624.57$ $\left.\mathrm{kg} \mathrm{ha}^{-1} \mathrm{DM}\right)$ and $10,849.44 \mathrm{~kg} \mathrm{ha}^{-1}$ of $\mathrm{GB}\left(2,701.51 \mathrm{~kg} \mathrm{ha}^{-1} \mathrm{DM}\right)$, respectively.
Considering the biomass yield data from both studies (although the experiment happened at different growing seasons), it is possible to infer that the intercropping system is more advantageous in relation to the monocrop, since there was no reduction of maize biomass yield in the intercropping which added to the soybean biomass resulted in higher biomass yield, evidencing that the intercrop system increases biomass in relation to monocrop standing as a good option to optimize silage yield and quality. Moreover, soybean biomass yield in the intercropping presented considerable values of soybean biomass $\left(2,701.51 \mathrm{~kg} \mathrm{ha}^{-1} \mathrm{DM}\right)$, representing $11.1 \%$ of the ensiled dry matter, which can increase the amount of crude protein in the silage.

Maize biomass yield observed in both studies (1 and 2) were superior to those observed by Vieira et al. (2006), which evaluating 10 maize hybrids reported average yield of 45.59 and $18.17 \mathrm{t} \mathrm{ha}^{-1}$ of GB and DM, respectively. Higher biomass yield from studies 1 and 2 is possibly related to the good climatic conditions observed during the growing period of the crops (Figure 1), and soil fertility, associated to the productive potential of the used hybrid.

\section{Conclusions}

The addition of soybean biomass to corn silage provides $\mathrm{pH}$ changes and increases in ashes and crude protein content but does not affect digestibility (neutral and acid detergent fiber content and total digestible nutrients).

\section{Acknowledgments}

The authors are grateful to CAPES (Coordination for the Improvement of Higher Education Personnel - Finance Code 001) for the financial support and to Federal Technological University of Paraná (UTFPR), campus of Dois Vizinhos, for providing experimental field, machinery, and laboratories.

\section{Literature Cited}

Alvares, C.A.; Stape, J.L.; Sentelhas, P.C.; Gonçalves, J.L.M.; Sparovek, G. Köppen's climate classification map for Brazil. Meteorologische Zeitschrift, v.22, n.6, p.711-728, 2013. https:// doi.org/10.1127/0941-2948/2013/0507.

Ankom. Technology Method. 12-12-05. Rapid determination of oil/ fat utilizing high temperature solvent extraction. Macedon: AOAC, 2009. 2p. http://www.ssco.com.tw/Ankom/PDF_file/ Crude\%20Fat\%20Method.pdf. 12 Jun. 2019.

Baghdadi, A.; Halim, R.A.; Othman, R.; Yusof, M.M.; Atashgahi, A.R.M. Productivity, relative yield and plant growth of forage corn intercropped with soybean under different crop combination ratio. Legume Research - An International Journal, v. 39, n. 4, p. 558-564, 2016. https://doi.org/10.18805/Ir.vOiOF.10755.

Batista, V.V.; Adami, P.F.; Moraes, P.V.D.; Oligini, K.F.; Giacomel, C.L.; Link, L. Row arrangements of maize and soybean intercrop on silage quality and grain yield. Journal of Agricultural Science, v.11, n.2, p.286-300, 2019. https://doi.org/10.5539/jas.v11n2p286. 
Batista, V.V.; Adami, P.F.; Sartor, L.R.; Silveira, M.F.; Soares, A.B.; Oligini, K.F.; Kwiecinski, D.; Ferreira, M.L.; Camana, D.; Giacomel, C.L.; Fonseca, A.C. Forage yield and silage quality of intercropped maize+soybean with different relative maturity cycle. Journal of Agricultural Science, v.10, n.12, p.249-261, 2018. https://doi. org/10.5539/jas.v10n12p249.

Belel, M. D.; Halim, R. A.; Rafii, M. Y.; Saud, H. M. Intercropping of corn with some selected legumes for improved forage production: a review. Journal of Agricultural Science, v.6, n.3, p.48-62, 2014. http://dx.doi.org/10.5539/jas.v6n3p48

Bhering, S.B.; Santos, H.G.; Bognola, I.A.; Cúrcio, G.; Carvalho Junior, W.D.; Chagas, C.D.S.; Manzatto, C.V.; Áglio, M.L.D.; Silva, J.D.S. Mapa de solos do Estado do Paraná, legenda atualizada. In: In: Congresso Brasileiro de Ciência do Solo, 32., 2009, Fortaleza. Viçosa, MG: SBCS; Fortaleza, 2009. https://www.alice.cnptia.embrapa.br/alice/ bitstream/doc/578217/1/SP5507.pdf. 22 Jun. 2019.

Evangelista, A.R.; Resende, P. M.; Maciel, G.A. Uso da soja [Glycine $\max ($ L.) Merrill] na forma de forragem. Lavras: UFLA, 2003. 36p.

Ferreira, Daniel Furtado. SISVAR: um programa para análises e ensino de estatística. c, v. 6, n.2, p. 36-41, 2008. http://www.dex.ufla. $\mathrm{br} /$ danielff/meusarquivospdf/art63.pdf. 02 Jun. 2019.

Ghizzi, L.G.; Del Valle, T.A.; Silva, G.G.; Zilio, E.M.C.; Gheller, L.S.; Marques, J.A.; Silva, T.B.P.; Rennó, F.P. Silagem de planta inteira de soja (Glycine max L Merrill): Uma opção de volumoso na nutrição de ruminantes. In: Gobesso, A.A.O.; Rennó, F.P.; Balieiro, J.C.C.; Brunetto, M.A. (Orgs.). Novos desafios da pesquisa em nutrição e produção animal. Piracicaba: Programa de Pós-Graduação em Nutrição e Produção Animal; 5D editora, 2017. p. 110 - 128.

Gobetti, S.T.; Neumann, M.; Oliveira, M.R.; Oliboni, R. Produção e utilização da silagem de planta inteira de soja (Glicine max) para ruminantes. Ambiência, v.7, n.3, p.603-616, 2011. https://doi. org/10.5777/ambiencia.2011.03.02rb.

Goes, R.H.B.; Silva, L.H.X.; Souza, K.A. Alimentos e alimentação animal. Dourados: Universidade Federal da Grande Dourados, 2013. 81p.

Instituto Agronômico do Paraná - IAPAR. Sistema de monitoramento agroclimático do Paraná. 2019. http://www.iapar.br/modules/ conteudo/conteudo.php?conteudo=595. 29 Mar. 2019.

Jobim, C.C.; Calixto Junior, M.; Bumbieris Júnior, V.H.; Oliveira, F.C.L. Composição química e qualidade de conservação de silagens de grãos de milho (Zea mays L.) com diferentes níveis de grãos de soja (Glycine max Merril). Semina: Ciências Agrárias, v.31, n.3, p.773782, 2010. https://doi.org/10.5433/1679-0359.2010v31n3p773.

Keplin, L.A.S. Silagem de soja: uma opção para ser usada na nutrição animal. In: Simpósio Sobre Produção e Utilização de Forragens Conservadas, 2., 2004, Maringá. Anais... Maringá: Universidade Estadual de Maringá, 2004. p.161-171
Kim, J.; Song, Y.; Kim, D.W.; Fiaz, M.; Kwon, C.H. Evaluating different interrow distance between corn and soybean for optimum growth, production and nutritive value of intercropped forages. Journal of Animal Science and Technology, v. 60, n. 1, p. 1, 2018. https://doi.org/10.1186/s40781-017-0158-0.

Leonel, F. de P.; Pereira, J.C.; Costa, M.G.; De Marco Júnior, P.; Lara, L.A.; Sousa, D. de P.; Silva, C.J. da. Consórcio capim-braquiária e soja, produtividade das culturas e características qualitativas das silagens. Revista Brasileira de Zootecnia, v.37, n.11, p.2031-2040, 2008. https://doi.org/10.1590/S1516-35982008001100020.

Neves, M.I.R.; Gai, V.F. Temperatura, pH e qualidade bromatológica de silagem de milho com e sem inoculante. Revista Cultivando o Saber, v.10, n.4, p.447-457, 2017. https://www.fag.edu.br/ upload/revista/cultivando_o_saber/5a312d0072bb3.pdf. 20 Mar. 2019.

Pauli1, T.; Hoinosk, M.E.; Mascarelo, F.C.; Di Domenico, A.S.; Fioreli, A.B. Avaliação bromatológica de amostras de silagem de milho de propriedades rurais de Dois Vizinhos-PR. In: Congresso de Ciência e Tecnologia da Universidade Tecnológica Federal do Paraná, 4; Mostra Científica da Pós-Graduação da Universidade Tecnológica Federal do Paraná, 1., 2017, Dois Vizinhos. Anais... Dois Vizinhos: UTFPR, 2017. p.247-249.

Pionner. Análise bromatológica. http://www.pioneersementes.com. br/milho/silagem/analise-bromatologica. 09 Dez. 2019.

Silva, D.; Queiroz, A.D. Análise de alimentos (métodos químicos e biológicos). 3.ed. Viçosa: Universidade Federal de Viçosa. 2002. $166 p$.

Stella, L.A.; Peripolli, V.; Prates, Ê.R.; Barcellos, J.O.J. Composição química das silagens de milho e sorgo com inclusão de planta inteira de soja. Boletim de Indústria Animal, v.73, n.1, p.73-79, 2016. https://doi.org/10.17523/bia.v73n1p73.

Tedesco, M.J.; Gianello, C.; Bissani, C.A.; Bohnen, H.; Volkweiss, S.J. Análises de solo, plantas e outros materiais. Porto Alegre: Universidade Federal do Rio Grande do Sul, 1995. 176p.

Tsujimoto, Y.; Pedro, J.A.; Boina, G.; Murracama, M.V.; Ito, O.; Tobita, S.; Oya, T.; Cuambe, C.E.; Martinho, C. Performance of maizesoybean intercropping under various $\mathrm{N}$ application rates and soil moisture conditions in Northern Mozambique. Plant Production Science, v. 18, n. 3, p. 365-376, 2015. https://doi.org/10.1626/ pps.18.365.

Van Soest, P.J. Nutritional ecology of the ruminant. 2.ed. New York: Cornell University Press, 1994. 476p.

Vieira, A.F.; Nunes, R.L.C.; Torres, R.A.; Dias, N.S.; Oliveira, A.B. Avaliação agronômica de híbridos de milho para silagem em Baraúna, região semiárida nordestina. Revista Brasileira de Milho e Sorgo, v. 14, n. 2, p. 283-290, 2015. https://doi. org/10.18512/1980-6477/rbms.v14n2p283-290. 